\title{
Improvement of Power System Stability Using FACTS Device
}

\author{
Zsolt Čonka ${ }^{1 *}$, Michal Kolcun ${ }^{2}$, Michal Kolcun Jr. ${ }^{3}$, Jozef Dudiak $^{4}$, Miroslav Mikita $^{5}$, Martin Vojtek ${ }^{6}$ \\ ${ }^{1-6}$ Technical University of Košice
}

\begin{abstract}
This paper describes the impact of the Flexible AC Transmission System (FACTS) controller, namely Thyristor Controlled Series Capacitor (TCSC), on the transient stability of power transmission. For demonstration of the impact of TCSC on transient stability of a power system, a model of the Slovak power system was used. The devices with a suitable controller can also be used for many other purposes than those for which they were designed.
\end{abstract}

Keywords - Power system stability, Thyristor Controlled Series Capacitor (TCSC), transient stability.

\section{INTRODUCTION}

Research of the Flexible Alternating Current Transmission System (FACTS) devices began in the 80s of the 20th century [1]. One of the main tasks of the regulators was to improve the stability of electricity transmission. Improving the dynamic stability means the increase in the maximum transmission capacity in the system without losing synchronism [2]. The probability of the loss of stability depends on the size of the transmitted power before failure. The dynamic stability of power system is influenced by many factors such as admittance, duration of failure, regulation of excitation).

Thyristor Controlled Series Capacitor (TCSC) allows continuously changing the admittance, which is a very important variable affecting the stability of the system [3].

\section{TCSC}

TCSC consists of a capacitor that is connected parallel to a thyristor regulated reactor. This configuration allows for a smooth change of the impedance of the transmission lines and a smooth control of a wide-range frequency of the capacitance. For a proper function of TCSC, its control is very important.

The control of the reactance of TCSC is a very complex and dynamic process. The efficiency and effect of TCSC are very dependent on the calculation accuracy of the TCSC reactance at a particular moment. In case of a wrong calculation of the reactance, an opposite effect than that provided by TCSC may occur.

The Fig. 1 shows the main scheme of TCSC. It consists of three parts: capacitor battery $C$, parallel connected reactor $L$, and the thyristors VT1 and VT2 [5].

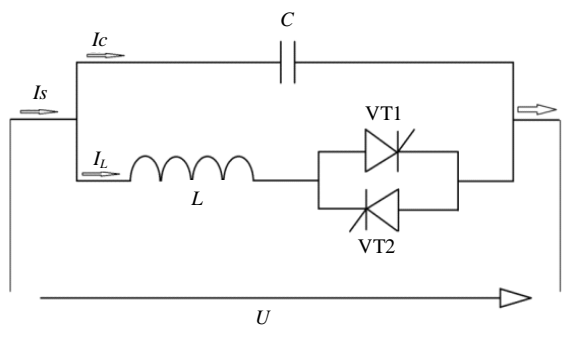

Fig. 1. Scheme of the TCSC.

$$
\begin{aligned}
& i_{C}=C \cdot \frac{d v}{d t} \\
& i_{L}=L \cdot \frac{d i_{L}}{d t} \\
& i_{\mathrm{S}}=i_{C}+i_{L}
\end{aligned}
$$

where

$I_{C}$ and $I_{L}$-instantaneous current of the capacitor and reactor; $i_{\mathrm{S}}-$ instantaneous current of a controlled line.

TCSC can be controlled by changing the opening angle of the thyristor $\alpha$, which is modifying the frequency of the capacitor. Equation (1) shows the relationship between the opening angle of the thyristor $(\alpha)$ and the reactance $X_{\mathrm{TCSC}}(\alpha)$ :

$$
\begin{aligned}
& X_{\mathrm{TCSC}}(\alpha)=X_{C}-\frac{X_{C}^{2}}{\left(X_{C}-X_{\mathrm{P}}\right)} \cdot \frac{\sigma+\sin \sigma}{\pi}+\frac{4 X_{C}^{2}}{\left(X_{C}-X_{\mathrm{P}}\right)} . \\
& \frac{\cos ^{2}\left(\frac{\sigma}{2}\right)}{\left(k^{2}-1\right)} \cdot \frac{\left(k \cdot \operatorname{tg}\left(\frac{k \cdot \sigma}{2}\right)-\tan \left(\frac{\sigma}{2}\right)\right)}{\pi}
\end{aligned}
$$

where

$X_{C}$ - capacitance of the capacitor;

$X_{\mathrm{P}}$ - inductive reactance of the reactor connected parallel to the condenser;

$\sigma=2(\pi-\alpha)-$ opening angle of TCSC controller;

$k=\sqrt{\frac{X_{C}}{X_{\mathrm{P}}}}-$ compensation ratio.

\footnotetext{
* Corresponding author.

E-mail address: zsolt.conka@tuke.sk
} 
$X_{\mathrm{TCSC}}(\alpha)$ is a unique feature by which we can continuously change the TCSC reactance. TCSC can operate in a capacitive or inductive mode, but the transition from one mode to another should be made avoiding resonance. TCSC is modeled as a variable capacitor that is limited only by the regulatory scope of the angle $\alpha$.

The Control range of TCSC is:

$$
X_{\mathrm{TCSC}}(\min ) \leq X_{\mathrm{TCSC}}(\alpha) \leq X_{\mathrm{TCSC}}(\max ),
$$

where

$X_{\mathrm{TCSC}}(\min )=X_{\mathrm{TCSC}}\left(180^{\circ}\right)-$ thyristor in permeable state;

$X_{\mathrm{TCSC}}(\max )=X_{\mathrm{TCSC}}\left(\alpha_{\min }\right)-$ thyristor of trailing state [5].

\section{TRANSIENT STABILITY}

Synchronous machines are mainly used in the PS as synchronous generators, synchronous motors and synchronous compensators. These devices are interconnected through transformers and lines and they are in parallel and synchronous operation. The transfer capability of such systems is limited by the permissible voltage drops and with the power-handling capacity. The transmission at large distance has been treated till the condition of stability of parallel operation. Prerequisite for the existence and operation of large interconnected power systems is the steady stability of parallel, i.e., synchronous operation. Synchronization power of synchronous machine allows us to do synchronous operation. This power presents the increase in the transmitted power at an increase of the load angle of the generator rotor over $1^{\circ}$ [2], [3]. The swing of the generator rotor due to changes in the electromagnetic energy that is accumulated in the magnetic circuits of the machine so arises additional power. This power can take positive and also negative values, which is reflected as a contribution to the performance of $\Delta P$ as braking, or acceleration of the machine [8], [9].

The role of synchronous machines not the retention of the synchronism. Co-operation of synchronous machines cannot be at arbitrarily large power. The steady-state operation of the whole system depends on its electrical, mechanical and electromagnetic parameters.

If the conditions of transfer are not violated, we can reach a stable maximum output with smoothly increasing the transmitted power. The considerations of static stability can be applied for small swings of the machine. In operation, there are many sudden changes in the system (switching processes, shock loads, short circuits). Due to the unbalance of the consumption and production of the electric power, the load angle values can achieve major changes. These change the load angle with leap. After these changes, the system goes into a new system state with electromechanical oscillations. Inertia of the machine is not allowing an immediate changes in the operating mode (angle $\delta$ ) course the parameters oscillations may be stabilized at a new constant, or continue to increase. In the latter case, a loss of stability occurs. In examining the transient stability, a constant value of the transition electromotive alternator voltage $E$ is generally assumed [2], [3], [8], [9].

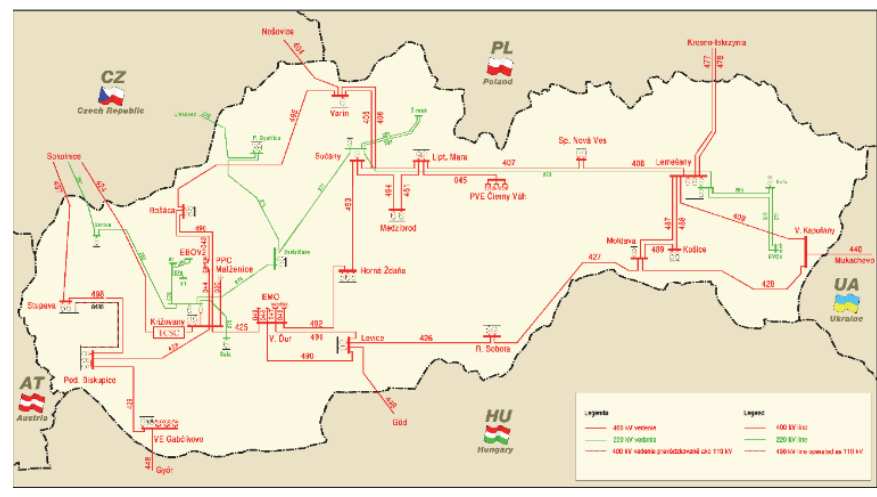

Fig. 2. Modelled network of the Slovak power system.

Fig. 2 displays the modelled network of the Slovak power system with installed TCSC to series with the line 424 in the substation of Križovany. Line 424 is an interconnecting line between Slovakia and the Czech Republic. The designed TCSC has the maximal allowed current loading - $2000 \mathrm{~A}$. The line 424 has the same maximum allowed current loading.

The most frequently occurring faults in the power system, affecting the stability of the whole system are:

- short circuit on the line,

- power source outage,

- short circuit on the busbar,

- power lines outage,

- step change in load.

To investigate the impact of TCSC device on transient stability of the power system, different types of disturbances were modelled:

1) three-phase short circuit on line 495;

2) outage of a reactor in the Mochovce nuclear power plant;

3) three-phase short circuit on the busbar in the P. Bystrica substation;

4) outage of line 492;

5) step change in the load in the Bošaca substation $(+200 \mathrm{MW})$.

In each of these cases, graphs of the active power of generators in the nuclear power plants in Mochovce and Jaslovske Bohunice were plotted. These generators have been chosen because they are the largest in the Slovak power system and the loss of synchronism in any of these generators cause significant fluctuations in the power system [8], [9].

\section{SIMULATIONS}

In Slovak power system, a three-phase short circuit was simulated at the end of the line V490 in the substation Levice.

The duration of the short circuit was set according to the instructions of ENTSO-E for the simulation of dynamic phenomena in the system. 
Clearance time of the short circuit at voltage levels $220 \mathrm{kV}$, $330 \mathrm{kV}$ and $400 \mathrm{kV}$ was set at $0.150 \mathrm{~s}$. Clearance time consists of the following elements:

$$
T_{\text {total }}=T_{\text {protection }}+T_{\text {switch }}+T_{\text {sec }}=0.150 \mathrm{~s} \text {. }
$$

At the time of $0.1 \mathrm{~s}$, the $3 \mathrm{f}$ short circuit occurs on line V490. By action of protective devices, the line will be disconnected in $0.25 \mathrm{~s}$. The impact of this disturbance on the transient stability was analyzed on the generator operating in the first block of the Mochovce nuclear power plant (NPP).

Fig. 3 shows the swings of the active power of the generator operating in the Mochovce NPP during and after the threephase short circuit on line V490 in the Levice substation. The red curve shows the swing of the generator with an installed TCSC device in series with the line V424; the blue curve shows the swings of the generator without TCSC.

Besides, Fig. 3 demonstrates the beneficial effect of TCSC on the transient stability of the power system. Settling time of active power swings was shorter with TCSC for almost 2 seconds. Also, the negative effect of TCSC on the transient stability of the power system is seen. By utilizing TCSC, the size of the first swing was larger by $100 \mathrm{MW}$. Too large first swing of the generator can result in a loss of its synchronism.

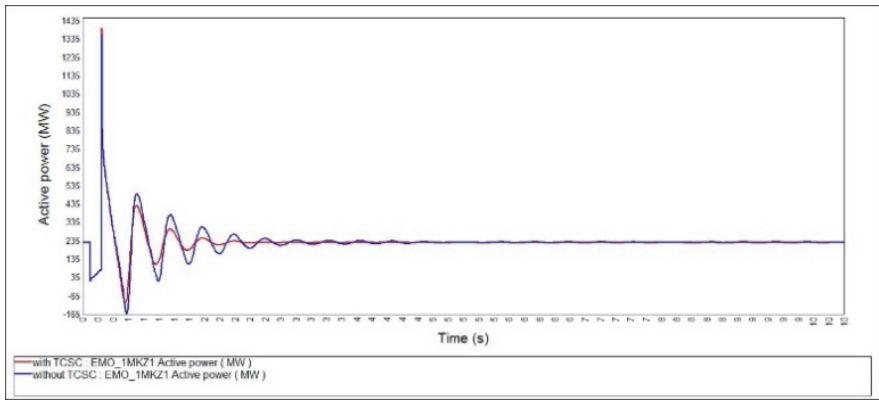

Fig. 3. Active power of the generator during the three-phase short circuit on line.

At the time of $0.1 \mathrm{~s}$, a $3 f$ short circuit occurs on the busbar at Spišská Nová Ves. By action of protective devices, the short circuit will be cleared at $0.25 \mathrm{~s}$. The impact of this disturbance on the transient stability was analyzed on the generator operating in the first block of the Mochovce nuclear power plant.

Fig. 4 shows swings of the active power of the generator operating in the Mochovce NPP during the three-phase short circuit on the busbar in the Spišská Nová Ves power station. The red curve shows the swing of the generator with installed TCSC device in series with the line V424; the blue curve shows the swings of the generator without TCSC. It is seen that TCSC has a positive effect on the transient stability of the power system. Settling time of the active power swings with TCSC was shorter, and the size of power swings was smaller.

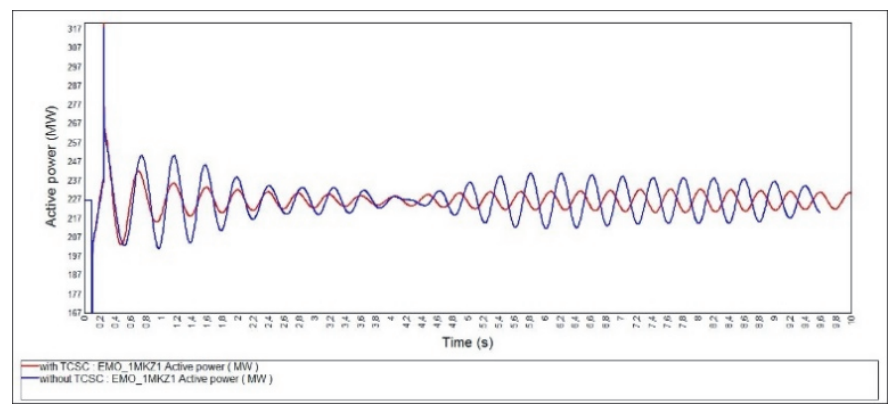

Fig. 4. Active power of the generator during the three-phase short circuit on the busbar.

At the time of $0.1 \mathrm{~s}$, a $200 \mathrm{MW}$ load in the busbar at Bošaca was switched on. The impact of this disturbance on the transient stability was analyzed on the generator operating in the first block of the Mochovce nuclear power plant.

Fig. 5displays swings of the active power of the generator operating in the Mochovce NPP during switching on the 200 MW load in the busbar at Bošaca. The red curve shows the swing of the generator with installed TCSC device in series with the line V424; the blue curve shows the swings of the generator without TCSC.

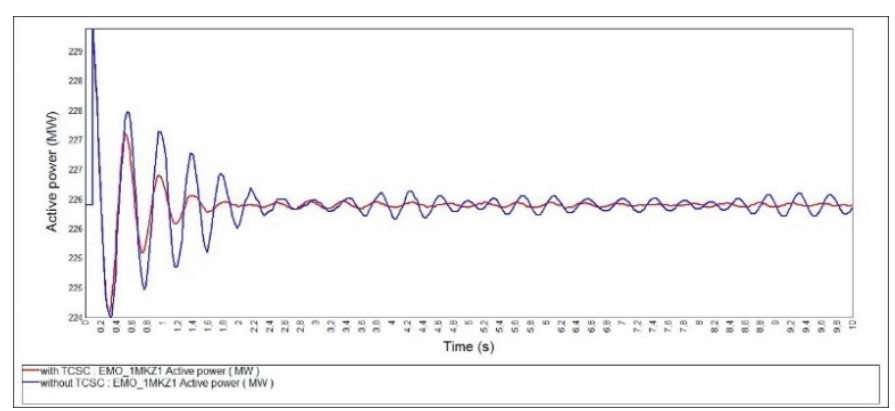

Fig. 5. Active power of the generator during the step change in load.

Fig. 5 also shows the beneficial effect of TCSC on the transient stability of the power system. Settling time of active power swings was shorter with TCSC for almost 13 seconds.

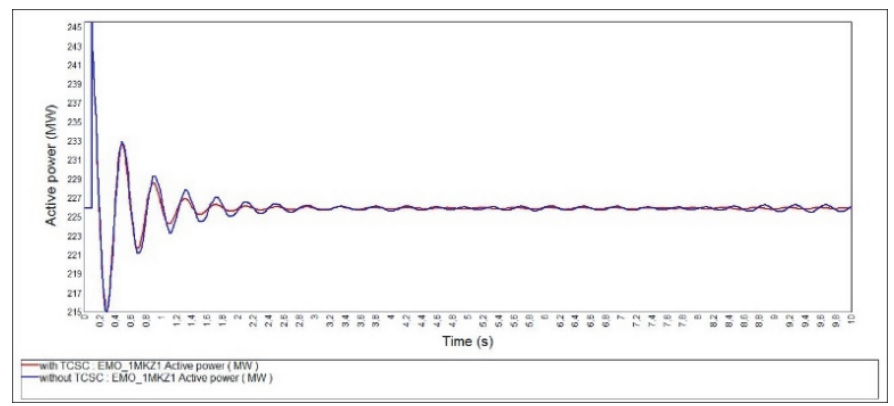

Fig. 6. Active power of the generator during the outage of the reactor in a nuclear power plant.

At the time of $0.1 \mathrm{~s}$, one of the reactors in the Mochovce NPP was switched off. The impact of this disturbance on the transient stability was analyzed on the generator operating in the second block of the Mochovce nuclear power plant. 
Fig. 6 demonstrates swings of the active power of the generator operating in the second block of the Mochovce NPP during the switching off the reactor in the Mochovce NPP. The red curve shows the swing of the generator with installed TCSC device in series with the line V424; the blue curve shows the swings of the generator without TCSC.

It is seen that TCSC has a positive effect on the transient stability of the power system. Settling time of the active power swings with TCSC was shorter, and the size of power swings was smaller.

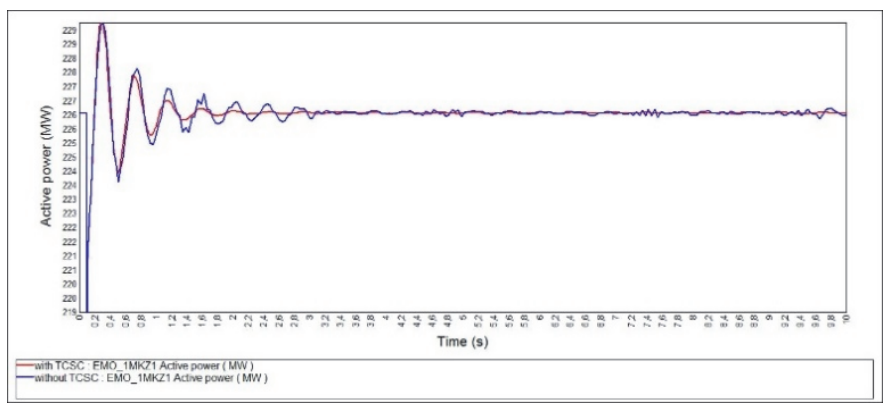

Fig. 7. Active power of the generator during the outage of line.

At the time of $0.1 \mathrm{~s}$, the line V448 was switched off. The impact of this disturbance on the transient stability was analyzed on the generator operating in the first block of the Mochovce nuclear power plant.

Fig. 7 demonstrates the swings of the active power of the generator operating in the Mochovce NPP during and after switching off the line V448. The red curve shows the swing of the generator with an installed TCSC device in series with the line V424; the blue curve shows the swings of the generator without TCSC.

Fig. 7 shows the beneficial effect of TCSC on the transient stability of the power system. Settling time of the active power swings was shorter with TCSC for 3 seconds.

\section{CONCLUSION}

This paper presents the importance and possibilities of improving transient stability of a power system. Installation of new FACTS devices to transmission system in the near future may be necessary to maintain the reliability and quality of the electricity supplied. Installation of such equipment is very costly, therefore it is important to choose the most appropriate device and the most suitable destination for its location. Today, the application of these devices is hampered mainly because of their price; however, we should consider what economic damage can be caused by a several-hours long blackout which can be avoided by installing FACTS devices.

\section{ACKNOWLEDGMENT}

This work was supported by the Slovak Research Agency No. VEGA 2/0071/16 project.

\section{REFERENCES}

[1] M. A. Abido, "Power system stability enhancement using FACTS controllers: A review," [Online]. Available: http://ajse.kfupm.edu.sa/ articles/341B_P.12.pdf. Accessed on: Feb. 5, 2012.

[2] Z. Trojánek, J. Hájek and J. Kvasnica, "Prěchodné jevy v elektrizačních soustavách,” STNL, 1987, 202-231 s.

[3] L. Reiss et al. "Teoretická elektroenergetika II," STNL, Praha, Bratislava: Alfa, 1978.

[4] B. Cintula, "Analýza dynamickej stability synchrónneho generátora," [Online]. Available: http://www.posterus.sk/?p=11726. Accessed on: Feb. 12, 2012.

[5] FACTS Powerful systems for flexible power transmission. [Online]. Available: http://www05.abb.com/global/scot/scot221.nsf/veritydisplay/ b0f2c8c94b48a6bcc1256fda003b4d42/\$file/facts_\%20eng.\%20abb\%20r eview.pdf. Accessed on: Feb. 5, 2012.

[6] G. N. Hingorani and L. Gyugyi, "Understanding FACTS," ISBN 0-78033455-8, IEEE Order No. PC5713.

[7] D. Revákova, Ž. Eleschová and A. Belán̆, "Prechodné javy v elektrizačných sústavách," ISBN 978-80-227-2868-3.

[8] Z. Čonka, "Výskum zariadení pre zlepšenie dynamickej stability elektrizačnej sústavy," Dissertation thesis, Košice, Sovak Republic, 2015.

[9] Z. Čonka and M. Kolcun, "Impact of TCSC on the Transient Stability," Acta Electrotechnica et Informatica, vol. 13, no. 2, pp. 50-53, 2013, ISSN 1335-8243. 